\title{
Diagnosis of Trypanosoma cruzi Chronic Infections in Humans: Usefulness of the Complement Regulatory Protein Antigens and Lytic Antibodies in the Control of Cure
}

\author{
AU Krettli \\ Centro de Pesquisas René Rachou-Fiocruz, Caixa Postal 1743, 30190-002 Belo Horizonte, MG, Brasil and \\ Universidade Federal de Minas Gerais
}

Key words: Trypanosoma cruzi - diagnosis - lytic antibodies - chronic infections

Chagas disease, highly prevalent in Central and South America, is caused by the hemoflagellate, protozoan, Trypanosoma cruzi transmitted mainly by vector contamination and blood transfusion. The parasite is found in the vertebrate host in two stages: trypomastigotes and amastigotes. The trypomastigotes are first inoculated as metacyclics, which invade the host mucosa or the broken skin, through contaminated feces and urine of the triatoma vector. They transform and divide as intracellular amastigotes, the multiplicative forms, to emerge as trypomastigotes, which circulate in the blood and re-invade various cells, promiscuously. The amastigotes are intracellular but may maintain the cycle without trypomastigotes, as demonstrated in vitro with stage specific monoclonal antibodies by Andrews et al. (1987).

The infection has an acute parasitemic phase, which lasts 1-2 months, often with no symptoms, and a chronic pauciparasitemic phase. Parasite multiplication at the acute phase is followed by inflammatory reactions at the site of inoculation (delay-type hypersensitvity at the eye mucosa or skin), satelity lymphadenitis, and, other acute inflammatory reactions (fever, splenomegaly, loss of weight, weakness, myalgia), more severe in infections induced by high inocula, including in accidental, non-treated laboratory infections in humans. Serology is useful for diagnosis of the acute phase, based on high levels of IgM anti-T. cruzi measured by tests with fixed epimastigotes from axenic cultures or with recombinant antigens specific of trypomastigote or amastigote.

Diagnosis of chronic Chagas disease (CCD) relays chiefly on conventional serology (CS) i.e.

Fax:+55-31-295.3115.

E-mail: akrettli@netra.cpqrr.fiocruz.br

Received 9 June 1999

Accepted 9 August 1999 indirect immunofluorescence (IIF), ELISA, hemagglutination and complement fixation reaction. Although infections are thought to be life-long, detection of parasites is difficult in CCD. It requires indirect methods of parasite amplification (hemocultures and xenodiagnosis, reviewed in Chiari et al. 1989, Chiari 1992), not used in clinical routine. Both are rather fastidious, slow, of low efficiency and time consuming. Such techniques are not yet replaced by modern techniques of molecular biology, presently reviewed by Chiari. Blood sub-inoculations in mice (babies or adults immunosuppressed) is also helpful to uncover parasites during CCD.

The xenodiagnosis is the more used parasitological test and gives consistent results in the literature, differently from hemocultures. In several different studies of xenodiagnosis and hemocultures in parallel, the former was almost always more efficient (8/11 reports) as reviewed by Junqueira (1996). Its drawn back is the invasiveness represented by the need of hundreds of bites when the vector feeds on the patient, and injects saliva, resulting in local allergies. Although such problem is easy to overcome by artificial feeding through membranes an additional problem is the use of serial xenodiagnosis, proven to increase the test positivity from 30-40\% in one test (Schenone et al. 1974) to about $70 \%$ in three tests (Coura et al. 1991).

The sensibility of hemocultures varies from $0 \%$ to $98 \%$ in the literature according to the volume of blood, the temperature for maintaining and processing it, anticoagulants and culture medium used, time of culture, i.e. 4-6 months of culture with monthly exams are recommended before a negative test is released (Galvão et al. 1989, Luz et al. 1994). We selected hemocultures to follow up treated patients. Among them one third have parasitological tests positives, even though about $90 \%$ remained positive by CS (Cançado 1985, Ferreira 1990). However, in spite of positive CS, 30-40\% of such treated patients lack functional antibodies 
indicative of ongoing infections detected by complement mediated lysis (CoML) first described in Krettli and Nussenzweig (1977), Krettli et al. (1979), and Krettli (1984). Based on CS and lytic antibodies, three sub-groups of treated patients were proposed (Krettli et al. 1982): (i) treated noncured (TNC) with CS and CoML positives; (ii) "dissociated" with positive CS and negative CoML; (iii) cured with all tests negative. We consider all patients from the dissociated group as cured too, since they have no circulating parasites, based on negative hemocultures; however, this confirmation of cure in the presence of positive CS has been disputed and, unfortunately mostly ignored by the clinicians.

In malaria, like in CCD, CS may persist for decades after cure, even in patients who had had only one episode of the acute disease (Braga et al. 1998). However, considering the low efficacy of tests to uncover parasites in CCD, patients from the dissociated group of CCD may still harbor live infections, amastigotes, but no circulating trypomastigotes (based on repeatedly negative hemocultures). This question is difficult to approach in humans at least, and is yet a subject of speculation. The techniques of molecular biology, DNA fingerprints, PCR, or of DNA hybridization with amastigotes genes, may bring solutions for the dissociated group (reviewed by Chiari in this issue).

In mice with chronic infections, antibodies to living trypomastigotes are ideal markers of infection, absent in immunized non-infected mice, all negative by CoML, but positive by CS, as expected (Krettli \& Brener 1982). Negative serum conversion of CS tests was easily induced by treatment of acute or chronic infections in such mice. In tune with our previous data in mice and with the hypothesis of positive CS after therapeutic cure, are the recent data on children treated at early chronic infections, in a phase III trial of benznidazole (Andrade et al. 1996). Negative ELISA tests occurred in 37 of the 58 treated children, as compared to three negative children among the 54 placebo-treated group. The antigen used for ELISA was a highly specific carbohydrate-rich trypomastigote antigen. Like in our patients with dissociated serology, most benznidazole treated-children remained clearly positive by CS, although at lower antibody titers of IIF during the following two years.

The use of purified antigens or antigens shed in cell cultures by trypomastigotes shows consistent negative in ELISAs in our dissociated treated-groups (Gazzinelli et al. 1993, Krautz et al. 1994) the best antigen being the recombinant Tc24, a calcium binding flagelar protein (Krautz et al. 1995), kindly pro- vided by Ali Ouaissi, from the Lille-Pasteur Institute. The specificity of the lytic antibodies relates to glycoconjugates. Not surprisingly, normal sera with anti-alfa-galactosyl antibodies, when highly concentrated, induced complement lysis of the otherwise resistant trypomastigote forms (Almeida et al. 1991). Lytic antibodies are also elicited by inoculation of mice with attenuated trypomastigotes and with antigens shed into the culture media (Umezawa et al. 1993). Other approaches to discover the target of the lytic antibodies show a number of potential targets, their relationship at the present not being yet understood (review submitted). Thus, the first antigen specific target for lytic antibodies was the $160 \mathrm{kDa}$ protein, stage specific of trypomsatigotes, absent in epimastigotes. Shown on Western blot, with sera from chronic infections in humans and mice, this protein was not recognized by sera with negative CoML, including from immunized mice and from the dissociated treated-patients (Martins et al. 1985). Attempts to purify and clone the gene encoding the $160 \mathrm{kDa}$ antigen, based on size purification, proved difficult (Norris et al. 1989). There is more than one protein of this size expressed by trypomasatigotes with many functional and biochemical characteristics revealing a family of surface trans-sialidase glycoproteins (Schenkman et al. 1994) but the protein isolated from trypomastigote culture media is expressed only in this stage (Norris et al. 1989). The $160 \mathrm{kDa}$ protein target of lytic antibodies is developmentally regulated, poorly expressed on the trypomastigote surface, and rather labile. These explain why antibodies to this protein are like to disappear soon after the trypomastigote stage is cleared, in treated CCD.

Humans and mice, with a past of chronic infection eliminated by chemotherapy, may remain with CS positive for decades due to other parasite antigens trapped in macrophages (Andrade et al. 1991) but stop to produce antibodies to living trypomastigotes. It is clear that $T$. cruzi has evolved a mechanism which allows metacyclic trypomastigotes to evade complement activation (C) lysis, the first mechanism of defense in the host's natural immunity. Its multiplicative insect form, the epimastigote, is susceptible to lysis. The mechanism of $\mathrm{C}$ resistance is attributed to the presence of regulatory proteins on the parasite surface and indeed, C3bi is found on the surface of circulating blood trypomastigote (Krettli \& Pontes de Carvalho 1985). Lytic antibodies from chronic infections render the trypomastigotes sensitive to lysis, primarily, via the alternative complement cascade (Krettli et al. 1979) being that fragments of IgG, in the absence of $\mathrm{Fc}$, are sufficient to trigger lysis (Kipnis et al. 1985). The epitope gene for lytic antibodies cloned by Norris et al. (1997) was trans- 
fected to epimastigotes and converted then into cells resistant to complement lysis. Such $T$. cruzi gene encoding a complement regulatory protein should allow conclusive understanding of the mechanisms of susceptibility to trypomastigote for lytic antibodies and whether the antibodies from other specificities, including normal anti-laminin antibodies and lytic IgG from acute infected hosts, act by the same mechanism. Since epimastigotes are easy to grown on liquid medium, once transfected with the complement regulatory protein (CRP) gene they should be used in the biological tests for functional lytic antibodies, indicative of T. cruzi infection.

\section{REFERENCES}

Almeida IC, Milani SR, Gorin PAJ, Travassos LR 1991. Complement-mediated lysis of Trypanosoma cruzi trypomastigots by human anti-a-galactosyl antibodies. J Immunol 146: 2394-2400.

Andrade ALSS, Zicker F, Oliveira RM, Silva SA, Luquetti A, Travassos LR, Almeida IC, Andrade SS, Andrade JG 1996. Randomised trial of efficacy of benznidazole in treatment of early Trypanosoma cruzi infection. Lancet 348: 1407-1413.

Andrade SG, Freitas LAR, Peyrol AR, Sadigurski M 1991. Experimental chemotherapy of Trypanosoma cruzi infection: persistence of parasite antigens and positive serology in parasitologicaly cured mic. Bull WHO 69: 191-197.

Andrews NW, Hong KS, Robbins ES, Nussenzweig V 1987. Stage-specific surface antigens expressed during the morphogenesis of vertebrate forms of Trypanosoma cruzi. Exp Parasitol 64: 474-484.

Braga EM, Fontes CJF, Krettli AU 1998. Persistence of humoral response against sporozoite and blood-stage malaria antigens 7 years after a brief exposure to Plasmodium vivax. J Infect Dis 177: 1132-1135.

Cançado JR 1985. Tratamento específico, p. 285-288. In JR Cançado \& M Chuster (eds), Cardiopatia Chagásica, Fundação Carlos Chagas, Belo Horizonte.

Chiari E 1992. Diagnostic tests for Chagas disease. Parasitological diagnosis, p. 153-164. In S Wendel, Z Brener, ME Camargo \& A Rassi (eds), Chagas Disease (American Trypanosomiasis): its Iimpact on Ttransfusion and Clinical Medicine, ISBT, São Paulo.

Chiari E, Dias, JCP, Lana M, Chiari CA 1989. Hemocultures for the parasitological diagnosis of human chronic Chagas disease. Rev Soc Bras Med Trop 22: 19-23.

Coura JR, Abreu LL, Willcox HPF, Petana W 1991. Evaluation of the xenodiagnosis of chronic Chagas patients infected ten years or over in an area where transmission has been interrupted - Iguatama and Pains, west Minas Gerais State, Brazil. Mem Inst Oswaldo Cruz 86: 395-398.

Ferreira HDO 1990. Treatment of the undetermined form of Chagas disease with nifurtimox and benznidazole. Rev Soc Bras Med Trop 23: 209-211.
Galvão LMC, Cançado JR, Rezende DF, Krettli AU 1989. Hemocultures from chronic chagasic patients using EDTA or heparin as anticoagulants. Braz J Med Biol Res 227: 841-843.

Gazzinelli RT, Galvão LMC, Krautz G, Lima APCA, Cançado JR, Scharfstein J, Krettli AU 1993. Use of Trypanosoma cruzi purified glycoprotein (GP57/51) or trypomastigote-shed antigens to assess cure for human Chagas disease. Am J Trop Med Hyg 49: 625635.

Junqueira ACV 1996. Um Estudo sobre o Xenodiagnóstico, a Hemocultura e a Reação em Cadeia da Polimerase na Detecção do Trypanosoma cruzi Chagas, 1909 em Indivíduos na Fase Crônica da Infecção Chagásica, MSc Thesis, Instituto de Ciências Biológicas, Universidade Federal de Minas Gerais, Belo Horizonte, 181 pp.

Kipnis TL, Krettli AU, Dias da Silva W 1985. Transformation of trypomastigote forms of Trypanosoma cruzi into activators of alternative complement pathway by immune $\mathrm{IgG}$ fragments. Scand J Immunol 22: $217-226$.

Krautz GM, Coutinho MG, Galvão LMC, Cançado JR, Krettli AU 1994. Antígenos solúveis liberados por tripomastigotas de Trypanosoma cruzi utilizados no teste de ELISA para detectar cura em pacientes chagásicos após tratamento específico. Rev Soc Bras Med Trop 27: 199-207.

Krautz GM, Galvão LMC, Cançado JR, GuevaraEspinoza A, Ouaissi A, Krettli AU 1995. Use of a 24-kilodalton Trypanosoma cruzi recombinant protein to monitor cure of human Chagas disease. J Clin Microbiol 33: 2086-2090.

Krettli AU 1984. Protective antibodies in Trypanosoma cruzi infections: detection, functional activity and possible mechanisms of trypomastigote killing in vivo and in vitro. Mem Inst Oswaldo Cruz 79: 5965.

Krettli AU, Brener Z 1982. Resistance against Trypanosoma cruzi associated to anti-living trypomastigote antibodies. J Immunol 128: 2009-2012.

Krettli AU, Nussenzweig RS 1977. Presence of immunoglobulins on the surface of circulating trypomastigotes of $T$. cruzi resulting in activation of the alternative pathway of complement and lysis. PAHO Sci Publ 347: 71-73.

Krettli AU, Pontes de Carvalho LC 1985. Binding of $C_{3}$ fragments to the Trypanosoma cruzi surface in the absence of specific antibodies and without activation of the complement cascade. Clin Exp Immunol 62: 270-277.

Krettli AU, Weisz-Carrington P, Nussenzweig RS 1979. Membrane-bound antibodies to bloodstream Trypanosoma cruzi in mice: strain differences in susceptibility to complement-mediated lysis. Clin Exp Immunol 37: 416-423.

Krettli AU, Cançado JR, Brener Z 1982. Effect of specific chemotherapy on the levels of lytic antibodies in Chagas disease. Tran R Soc Trop Med Hyg 76: 334-340.

Luz ZMP, Coutinho MG, Cançado JR, Krettli AU 1994. Hemocultura: técnica sensível na detecção do Try- 
panosoma cruzi em pacientes chagásicos na fase crônica da doença de Chagas. Rev Soc Bras Med Trop 273: 143-148.

Martins MS, Hudson L, Krettli AU, Cançado JR, Brener Z 1985. Human and mouse sera recognize the same polypeptide associated with immunological resistance to Trypanosoma cruzi infection. Clin Exp Immunol 61: 343-350.

Norris KA, Harth G, So M 1989. Purification of a Trypanosoma cruzi membrane glycoprotein which elicits lytic antibodies. Infect Immun 57: 2372-2377.

Norris KA, Schrimpf JE, Szabo MJ 1997. Identification of the family encoding the 160-kilodalton Trypanosoma cruzi complement regulatory protein. Infect
Immun 65: 349-357.

Schenkman S, Eichinger D, Pereira MEA, Nussenzweig V 1994. Structural and functional properties of Trypanosoma cruzi trans-sialidase. Annu Rev Microbiol 48: 499-523.

Schenone H, Alfaro E, Rojas A 1974. Bases y rendimiento del xenodiagnóstico en la infección chagásica humana. Bol Chil Parasitol 29: 24-26.

Umezawa ES, Shikanai-Yasuda MA, Silveira JF, Cotrim PC, Paranhos G, Katzin M 1993. Trypanosoma cruzi: detection of a circulating antigen in urine of chagasic patients sharing common epitopes with an immunodominat repetitive antigen. Exp Parasitol 76: 352-357. 